University of Nebraska - Lincoln

DigitalCommons@University of Nebraska - Lincoln

Faculty Publications, Department of Statistics

Statistics, Department of

2001

Field-Scale Electrical Conductivity Mapping for Delineating Soil Condition

Cinthia K. Johnson

USDA-ARS

John Doran

University of Nebraska - Lincoln, jdoran1@unl.edu

Harold R. Duke

USDA-ARS

Brian J. Wienhold

University of Nebraska-Lincoln, Brian.Wienhold@ars.usda.gov

Kent M. Eskridge

University of Nebraska - Lincoln, keskridge1@unl.edu

See next page for additional authors

Follow this and additional works at: https://digitalcommons.unl.edu/statisticsfacpub

Part of the Statistics and Probability Commons

Johnson, Cinthia K.; Doran, John; Duke, Harold R.; Wienhold, Brian J.; Eskridge, Kent M.; and Shanahan, John F., "Field-Scale Electrical Conductivity Mapping for Delineating Soil Condition" (2001). Faculty Publications, Department of Statistics. 9.

https://digitalcommons.unl.edu/statisticsfacpub/9

This Article is brought to you for free and open access by the Statistics, Department of at DigitalCommons@University of Nebraska - Lincoln. It has been accepted for inclusion in Faculty Publications, Department of Statistics by an authorized administrator of DigitalCommons@University of Nebraska - Lincoln. 


\section{Authors}

Cinthia K. Johnson, John Doran, Harold R. Duke, Brian J. Wienhold, Kent M. Eskridge, and John F. Shanahan 


\title{
Field-Scale Electrical Conductivity Mapping for Delineating Soil Condition
}

\author{
Cinthia K. Johnson,* John W. Doran, Harold R. Duke, Brian J. Wienhold, \\ Kent M. Eskridge, and John F. Shanahan
}

\begin{abstract}
Traditional sampling methods are inadequate for assessing the interrelated physical, chemical, and biological soil properties responsible for variations in agronomic yield and ecological potentials across a landscape. Recent advances in computers, global positioning systems, and large-scale sensors offer new opportunities for mapping heterogeneous patterns in soil condition. We evaluated field-scale apparent electrical conductivity $\left(\mathbf{E C}_{\mathrm{a}}\right)$ mapping for delineating soil properties correlated with productivity and ecological properties. A contiguous section of farmland ( $250 \mathrm{ha})$, managed as eight fields in a no-till winter wheat (Triticum aestivum $\mathbf{L}$.)-corn (Zea mays L.)-millet (Panicum miliaceum $\mathbf{L}$.)-fallow rotation, was $\mathbf{E C}_{\mathrm{a}}$ mapped ( $\approx 0$ - to 30-cm depth). A geo-referenced soil-sampling scheme separated each field into four $\mathrm{EC}_{\mathrm{a}}$ classes that were sampled (0- to 7.5and 7.5- to 30-cm depths) in triplicate. Soil physical parameters (bulk density, moisture content, and percentage clay), chemical parameters (total and particulate organic matter [POM], total $\mathrm{C}$ and $\mathrm{N}$, extractable $\mathbf{P}$, laboratory-measured electrical conductivity $\left[\mathbf{E C}_{1: 1}\right]$, and $\left.\mathbf{p H}\right)$, biological parameters (microbial biomass $\mathrm{C}$ [MBC] and $\mathrm{N}$ [MBN], and potentially mineralizable $N$ ), and surface residue mass were significantly different among $\mathrm{EC}_{\mathrm{a}}$ classes $(P \leq 0.06)$ at one or both depths (0-7.5 and 0-30 cm). Bulk density, percentage clay, $\mathrm{EC}_{1: 1}$, and $\mathrm{pH}$ were positively correlated with $\mathbf{E C}_{\mathfrak{a}}$; all other soil parameters and surface residue mass were negatively correlated. Field-scale $\mathbf{E C}_{\mathrm{a}}$ classification delimits distinct zones of soil condition, providing an effective basis for soil sampling. Potential uses include assessing temporal impacts of management on soil condition and managing spatial variation in soil-condition and yield-potential through precision agriculture and site-specific management.
\end{abstract}

$\mathrm{T}$ HE HETEROGENEOUS NATURE of soil across a landscape has long been recognized; however, the lack of sensitive tools to detect subtle shifts among soil properties has limited spatial delineation of this variability. Recent technological advances in computer hardware and software, global positioning systems, and sensors for field-scale measurements offer new opportunities to map the complex patterns in soil condition that underlie and define agronomic yield potential. Field-scale sensor maps may provide a basis for soil-sampling strategies that accurately reflect spatial variation. Such sampling strategies may be useful in temporal analyses to monitor ecological trends and for managing inherent soil variability through precision agriculture. Site-specific management has the potential to maximize agricultural production and economic return while conserving soil and

C.K. Johnson, J.W. Doran, B.J. Wienhold, and J.F. Shanahan, USDAARS, 120 Keim Hall, Lincoln, NE 68583-0934; H.R. Duke, USDAARS, AERC-CSU, Ft. Collins, CO 80523-1325; K.M. Eskridge, Univ. of Nebraska, 103 Miller Hall, Lincoln, NE 68583. The USDA-ARS, Northern Plains Area is an equal opportunity/affirmative action employer and all agency services are available without discrimination. Journal Series No. 13291. Received 5 Sept. 2000. *Corresponding author (cjohnso2@bigred.unl.edu).

Published in Soil Sci. Soc. Am. J. 65:1829-1837 (2001). water resources and enhancing soil quality (Wallace, 1994). An essential first step to the successful implementation of site-specific management is the evaluation of new technologies at the field-scale (Vanden Heuvel, 1996).

Complex inter-relationships exist between physical, chemical, and biological soil properties and their response to land management; these factors are responsible for crop productivity and ecological potential (Bauer and Black, 1994; Gardner and Clancy, 1996; Olson et al., 1996). Soil condition is the combined characteristics of a given soil that define its level of function as a medium for crop production and a contributor to air and water quality. In this paper, we define ecological potential as the complementary interactions between the soil biological community and the soil environment that optimize soil condition and are determined by land management.

Different approaches have been used to detect and map soil condition patterns related to spatial variation in productivity. Lark (1997) used intensive grid sampling (20-m intervals), based upon soil texture and depth, to identify seven map units across a 6-ha field. He found significant differences among map units for several yield-related soil properties including percentage moisture and organic matter, mineral $\mathrm{N}$, and $\mathrm{pH}$ at 0 - to 20 $\mathrm{cm}$ depths $(P \leq 0.003)$. However, this type of intensive grid sampling is both labor intensive and costly, making it impractical at the farm-scale. Francis and Schepers (1997) used selective soil sampling based on soil color, texture, depth, slope, and erosion characteristics to produce fertilizer recommendation zones. These zones effectively partitioned concentrations of the nonmobile nutrients P, K, and Zn. Studies, such as these, underscore a need for cost-effective technology to assess spatial variation in soil condition at the field-scale.

Laboratory measurement of $\mathrm{EC}_{1: 1}$ is a useful integrator of soil physical, chemical, and biological factors that regulate soil function (Smith and Doran, 1996). Geo-referenced in situ estimates of $\mathrm{EC}_{\mathrm{a}}$ are now being made at the field scale using both direct contact sensors to measure resistance and noncontact sensors based upon electromagnetic induction technology (Dolittle et al., 1995; Jaynes et al., 1995; Jaynes, 1996). These two approaches provide highly correlated measures of $\mathrm{EC}_{\mathrm{a}}$ and both have been shown to correlate with crop productivity at topsoil depths to $90 \mathrm{~cm}$ (Fritz et al., 1999; Sudduth et al., 1999).

Measured soil $\mathrm{EC}_{\mathrm{a}}$ is determined by clay type and percentage, soil moisture (in conjunction with pore size,

Abbreviations: $\mathrm{EC}_{1 \cdot 1}$, laboratory-measured electrical conductivity using a 1:1 soil:water ratio; $\mathrm{EC}_{\mathrm{a}}$, field-scale apparent electrical conductivity; MBC, microbial biomass C; MBN, microbial biomass N; POM, particulate organic matter. 
tortuosity, and water-filled space as they vary with depth), salinity of the soil solution, and temperature (Rhoades et al., 1989; McNeill, 1980). For individual soils, one or more of these factors will dominate measured $\mathrm{EC}_{\mathrm{a}}$. Substantial research effort has been directed toward understanding location-specific relationships between $\mathrm{EC}_{\mathrm{a}}$ and those factors contributing to its measurement, including moisture (Khakural and Robert, 1998; Sheets and Hendrickx, 1995; Kachanoski et al., 1988), salinity (Lesch et al., 1992; Rhoades and Corwin, 1981; Rhoades and Ingvalson, 1971), and salinity and clay content (Williams and Hoey, 1987).

In addition to use as a direct indicator of those soil properties affecting it, it is also possible to use $\mathrm{EC}_{\mathrm{a}}$ as an indirect measure of other soil properties and productivity (Jaynes, 1996). The effectiveness of $\mathrm{EC}_{\mathrm{a}}$ mapping for predicting crop yield appears to depend upon the degree to which soil properties affecting yield are correlated with the soil factors affecting $\mathrm{EC}_{\mathrm{a}}$. Sudduth et al. (1995) found strong correlations during relatively dry years between both $\mathrm{EC}_{\mathrm{a}}$ and depth to claypan, and depth to claypan and yield. However, $\mathrm{EC}_{\mathrm{a}}$ was found to be a poor predictor of yield for claypan soils in a wet year. Strong correlations have also been shown between $\mathrm{EC}_{\mathrm{a}}$ and soil attributes linked to forest productivity including soil saturated-extract electrical conductivity, exchangeable $\mathrm{Ca}$ and $\mathrm{Mg}$, and cation-exchange capacity (McBride et al., 1990).

Most published research applies $\mathrm{EC}_{\mathrm{a}}$ mapping to the appraisal of one or two specific factors contributing to soil condition and productivity. However, there is little information in the literature regarding the use of $\mathrm{EC}_{\mathrm{a}}$ sensors to evaluate spatial variation in overall soil condition for arable land; where soil condition encompasses both soil characteristics that affect $\mathrm{EC}_{\mathrm{a}}$, and other soil characteristics affecting yield potential with which they may be correlated. The objective of this study was to assess $\mathrm{EC}_{\mathrm{a}}$ mapping as a basis for soil sampling design and for spatially delineating soil physical, chemical, and biological properties (0- to 7.5- and 0- to 30-cm depths) related to yield and ecological potential. This information is essential for monitoring the impact of management on temporal trends in soil condition and for the successful implementation of site-specific management.

\section{MATERIALS AND METHODS}

\section{Study Site}

This research was conducted as part of the newly established Farm-Scale Intensive Cropping Study. The site consists of a contiguous section of farmland, $\approx 250 \mathrm{ha}$, located $30 \mathrm{~km}$ east of Sterling, $\mathrm{CO}\left(40.6^{\circ} \mathrm{N}, 103.0^{\circ} \mathrm{W}\right)$. Centered within the semiarid Central Great Plains, the site receives highly variable rates of precipitation, ranging between 250 and $680 \mathrm{~mm}$ and averaging $420 \mathrm{~mm}$ annually. Typically, $80 \%$ of precipitation falls during the growing season between April and September. Soils are mapped as a complex of Platner (fine, smectitic, mesic Aridic Paleustolls), Weld (fine, smectitic, mesic Aridic Argiustolls), and Rago loam (fine, smectitic, mesic Pachic Argiustolls) and range in slope from 0 to $5 \%$

The site was managed for nearly $70 \mathrm{yr}$ as a winter wheatfallow rotation under conventional-tillage. During most of this time, it was farmed as eight fields of $\approx 31$ ha, four planted to wheat and four in fallow each year. Beginning in 1999, cropping was intensified to a wheat-corn-millet-fallow rotation using strict no-till management. By retaining the eight-field subdivisions within the section, each phase of the 4-yr rotation is duplicated each year (Fig. 1). Fields 1 and 4, 2 and 7, and 3 and 6 are paired (i.e., replicates) with regard to recent management history. Fields 5 and 8 have identical histories except

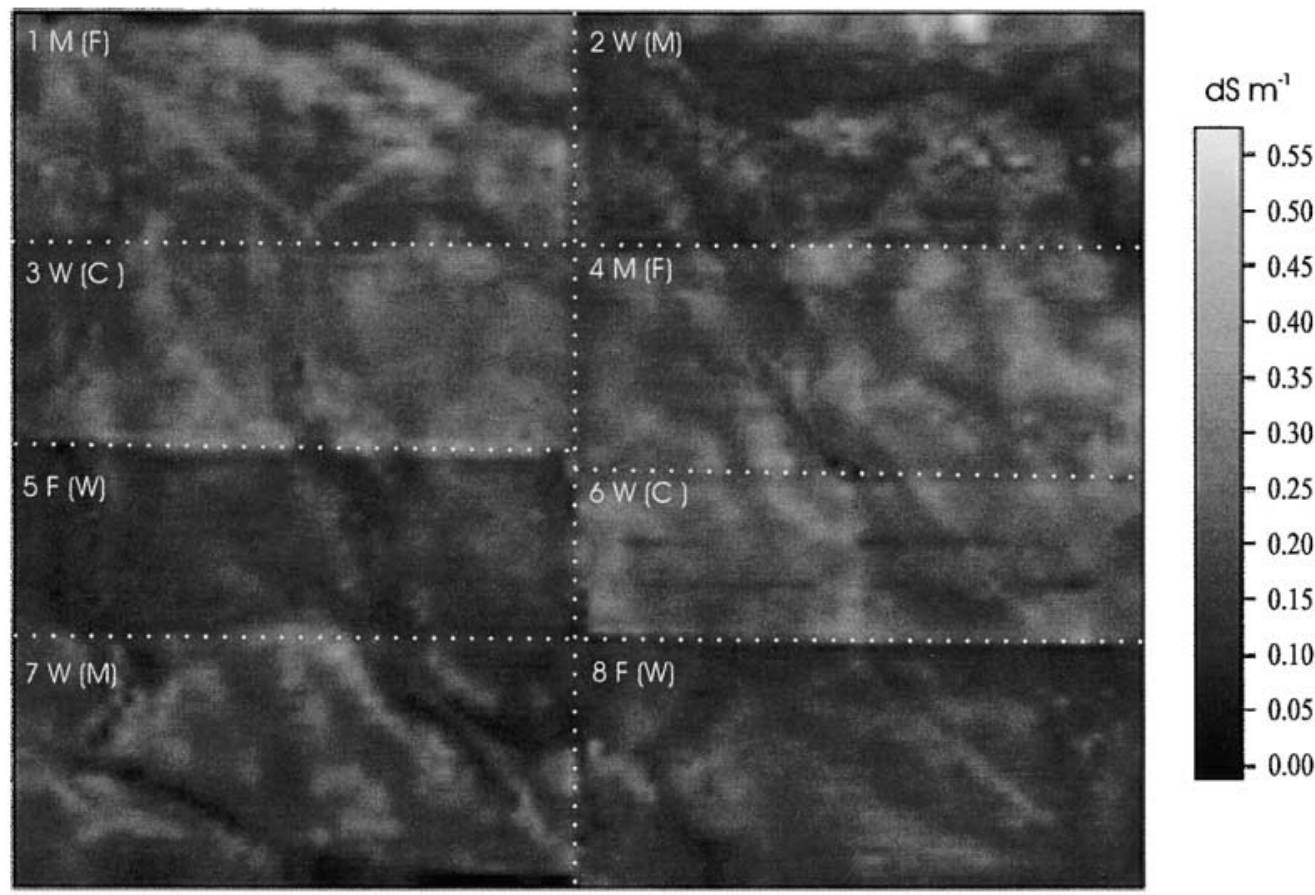

Fig. 1. Experimental layout superimposed on the March $1999 \mathrm{EC}_{\mathrm{a}}$ map of the 250 -ha site. Field numbers, followed by cropping treatments winter wheat (W), corn (C), proso millet (M), and fallow (F), for the 1998 and 1999 (in parenthesis) growing seasons are shown in the upper lefthand corner of each field. 
for 1997 when field 8 was planted to conventionally-tilled millet, while field 5 was left fallow.

\section{Electrical Conductivity Mapping}

Each of the eight fields comprising the study was individually mapped for $\mathrm{EC}_{\mathrm{a}}$, during mid-March 1999, using a Veris 3100 Sensor Cart (Veris Technologies, Salina, KS) ${ }^{1}$. At the time of mapping, winter wheat was growing in Fields 5 and 8; all other fields had been fallow since the summer of 1998 . The Veris 3100 Sensor Cart was pulled across each field behind a pick-up truck in a series of parallel transects spaced $\approx 15 \mathrm{~m}$ apart. The instrument was calibrated, as per manufacturer instructions, prior to data collection for each field.

The Veris 3100 uses three pairs of coulter-electrodes to determine soil $\mathrm{EC}_{\mathrm{a}}$. The coulters penetrate the soil surface to a depth of $\approx 6 \mathrm{~cm}$. One pair of electrodes functions to emit an electrical current into the soil, while the other two pairs detect decreases in the emitted current due to its transmission through soil (resistance). The depth of measurement is based upon the spacing of the coulter-electrodes. The center pair, situated closest to the emitting (reference) coulter-electrodes, integrates resistance between depths of 0 and $\approx 30 \mathrm{~cm}$, while the outside pair integrates between 0 and $\approx 90 \mathrm{~cm}$. Output from the Veris Data Logger reflects the conversion of resistance to conductivity $(1 /$ resistance $=$ conductivity). We used only surface data $(\approx 0-30 \mathrm{~cm})$ in this study since it corresponded most closely to soil sampling depths (described later).

A Trimble AG132 DGPS system (Trimble Navigation Ltd., Sunnyvale, CA) with submeter accuracy was used to georeference $\mathrm{EC}_{\mathrm{a}}$ measurements. The Veris data logger records latitude, longitude, and shallow and deep $\mathrm{EC}_{\mathrm{a}}$ data $\left(\mathrm{mS} \mathrm{m}^{-1}\right)$ at 1-s intervals in an ASCII text format. For reporting purposes, $\mathrm{EC}_{\mathrm{a}}$ units were converted to $\mathrm{dS} \mathrm{m}^{-1}$ by dividing $\mathrm{mS}$ $\mathrm{m}^{-1}$ by 100 . Given the average collection speed of $0.44 \mathrm{~m}$ $\mathrm{sec}^{-1}, \approx 250 \mathrm{EC}_{\mathrm{a}}$ measurements were taken per hectare.

\section{Electrical Conductivity Class and Soil Sampling Point Determination}

The soil sampling design used in this study represents a stratified sampling approach (Cook and Stubbendieck, 1986) with allocation into four geo-referenced $\mathrm{EC}_{\mathrm{a}}$ ranges. Data were sorted into $\mathrm{EC}_{\mathrm{a}}$ ranges in the following manner: Veris data were downloaded and saved as an image file using ERDAS Imagine (ERDAS Inc., Atlanta, GA). In this format, unsupervised classification (ERDAS, 1997) was performed to individually recode the eight fields in the study into four classes $\left(\mathrm{EC}_{\mathrm{a}}\right.$ ranges). Four was determined to be the number of classes that could be evaluated with a manageable number of soil samples given the large area of land encompassed by this

${ }^{1}$ Mention of a trademark, proprietary product or vendor does not constitute a guarantee of or warranty of the product by USDA nor imply its approval to the exclusion of other products that may be suitable.
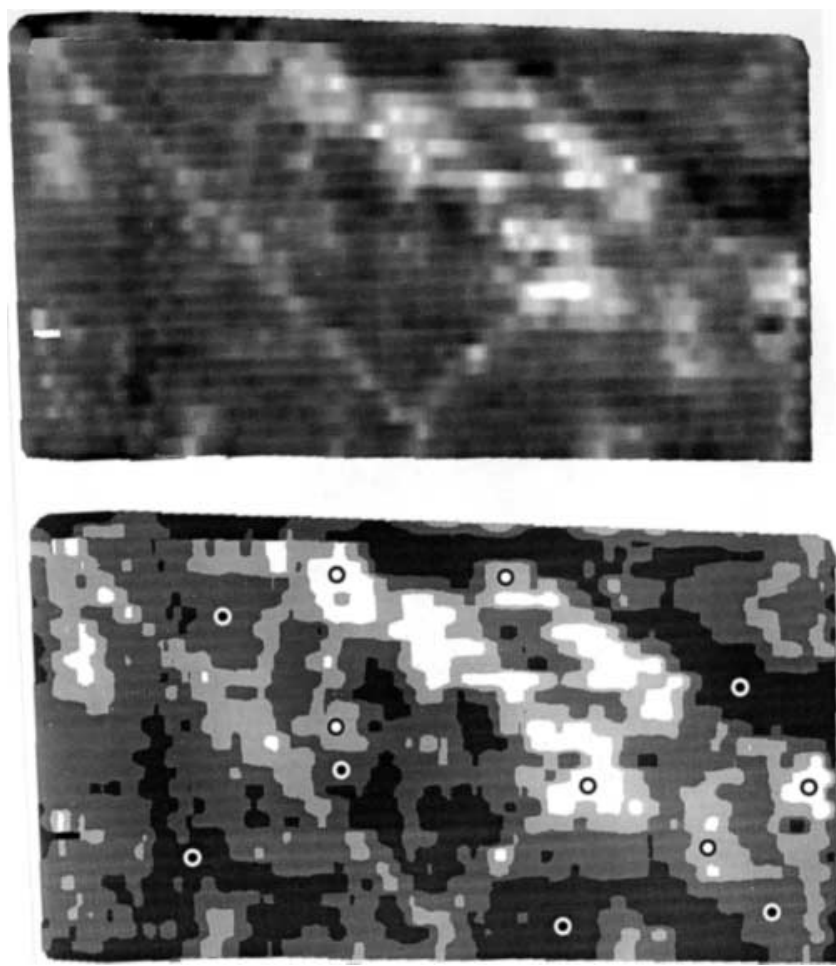

Fig. 2. A gray-scale electrical conductivity map for field 1 (top) and the same map following recoding into four electrical conductivity classes (bottom). Variations in color, from dark to light, correspond to increasing conductivity, and " $\bigcirc$ " symbols represent selected soil sampling sites.

study. Ranges of $\mathrm{EC}_{\mathrm{a}}$ were assigned to each class (e.g., field \#1 in Fig. 2, bottom) to reflect spectral patterns seen in the original gray-scale $\mathrm{EC}_{\mathrm{a}}$ maps (Fig. 2, top). In this way, unsupervised classification served to group $\mathrm{EC}_{\mathrm{a}}$ pixels into naturally occurring clusters. Table 1 shows $\mathrm{EC}_{\mathrm{a}}$ class ranges for individual fields, as well as $\mathrm{EC}_{\mathrm{a}}$ class means across all eight fields.

Three representative geo-referenced soil-sampling points were selected within each of the four $\mathrm{EC}_{\mathrm{a}}$ classes identified in each individual field (Fig. 2, bottom). Selections were made in distinct, nonadjoining areas within each class with the intent to provide comprehensive coverage of the experimental site. Sampling points were centered within $\mathrm{EC}_{\mathrm{a}}$ class areas to avoid transition zones. This process was used to identify 12 soilsampling points within each of the eight fields for a total of 96 points across the study site.

\section{Soil and Residue Sampling}

Given the significant amount of time required for $\mathrm{EC}_{\mathrm{a}}$ mapping, classification, and sample-site identification, particularly for an experiment of this size, simultaneous mapping and soil sampling were not possible. Soil samples were collected on

Table 1. Field-scale apparent electrical conductivity $\left(\mathbf{E C}_{\mathrm{a}}\right)$ class ranges within each field at the study site.

\begin{tabular}{|c|c|c|c|c|c|c|c|c|c|}
\hline \multirow{2}{*}{$\begin{array}{l}\mathbf{E C}_{\mathrm{a}} \\
\text { Class }\end{array}$} & \multirow{2}{*}{$\begin{array}{c}\text { EC }_{\mathrm{a}} \text { Class Means } \dagger \\
\left(\mathrm{dS} \mathrm{m}^{-1}\right)\end{array}$} & \multicolumn{8}{|c|}{ Field } \\
\hline & & 1 & 2 & 3 & 4 & $5 \ddagger$ & 6 & 7 & $8 \%$ \\
\hline & & & & & $-\mathbf{E C}_{\mathrm{a}} \mathbf{R a}$ & $\left.\mathbf{d} \mathbf{S} \mathbf{m}^{-1}\right)$ & & & \\
\hline I & .116 & $0-.17$ & $0-.12$ & $0-.17$ & $0-.15$ & $0-.10$ & $0-.17$ & $0-.12$ & $0-.12$ \\
\hline II & .168 & $.17-.23$ & $.12-.17$ & $.17-.21$ & $.15-.23$ & $.10-.14$ & $.17-.21$ & $.12-.16$ & $.12-.17$ \\
\hline III & .227 & $.23-.29$ & $.17-.28$ & $.21-.27$ & $.23-.28$ & $.14-.18$ & $.21-.28$ & $.16-.24$ & $.17-.21$ \\
\hline IV & .305 & $.29-.56$ & $.28-.78$ & $.27-.51$ & $.28-.42$ & $.18-.39$ & $.28-.45$ & $.24-.43$ & $.21-.44$ \\
\hline
\end{tabular}

$\dagger$ Mean $\mathbf{E C}_{\mathrm{a}}$ for each class across all fields.

₹ Fields planted to winter wheat at the time of $\mathrm{EC}_{\mathrm{a}}$ measurement. 
two different dates based upon crop status. Wheat and fallow fields were sampled in mid-August following wheat harvest. Corn and millet fields were sampled in mid-November after corn harvest. The rationale for two different sampling times is presented in the results and discussion section.

Soil samples were collected at depths of 0 to 7.5 and 7.5 to $30 \mathrm{~cm}$. Seven 4-cm diameter cores were taken at each sampling site, separated by depth, composited, and mixed. Because of high moisture contents, the 7.5 - to $30-\mathrm{cm}$ samples were sieved through a 4-mm screen, while the drier surface samples were sieved to $2 \mathrm{~mm}$. A portion of each sample was refrigerated at $4^{\circ} \mathrm{C}$, while the remainder was air dried. Deep samples were run through a soil grinder (M.G. Johnston Industries, Lakeville, MN) to pass a 2-mm sieve after air drying. The crushing action of this type of grinder leaves residues intact, and so does not interfere with the measurement of POM.

Soil temperature is known to fluctuate seasonally and to affect the measurement of $\mathrm{EC}_{\mathrm{a}}$. For this reason, duplicate soil temperature measurements were taken in surface soils (0-7.5 $\mathrm{cm}$ ) at each sampling site for both sampling dates.

As an estimate of productivity, surface residue cover was measured in wheat and fallow fields (Fields 1, 4, 5, and 8) at the time of soil sampling in mid-August. A representative area was selected $3 \mathrm{~m}$ south of each soil-collection site, and abovesurface residues were removed from an $85-\mathrm{cm}$ diameter area. Samples were oven-dried and mass per unit area was calculated $\left(\mathrm{kg} \mathrm{ha}^{-1}\right)$.

\section{Soil Analyses}

Physical, chemical, and biological soil attributes were assessed as per the minimum data set proposed by Doran and Parkin (1996). Physical measurements included soil texture (Kettler et al., in review), gravimetric water content, and bulk density. Bulk density was calculated for the composited soil cores collected at each site by dividing oven-dried mass by sample volume. Chemical measurements consisted of wholesoil organic matter and POM (0.053- to 0.5- and 0.5- to 2-mm size fractions) by loss on ignition (Cambardella et al., 2001), $\mathrm{pH}$ and $\mathrm{EC}_{1: 1}$ using a 1:1 water:soil mixture, $2 \mathrm{M} \mathrm{KCl-extracted}$ $\mathrm{NO}_{3}-\mathrm{N}$ and $\mathrm{NH}_{4}-\mathrm{N}$ measured on a LACHAT FIA auto-analyzer (Zellweger Analytics, Milwaukee, WI), total C and N analyzed with a Carlo Erba NA 100 (CE Elantech, Lakewood, NJ), and P by the Bray-1 method (Bray and Kurtz, 1945). Biological measurements included $\mathrm{MBC}$ and $\mathrm{MBN}$ by microwave irradiation (Islam et al., 1998) and anaerobically-incubated potentially-mineralizable $\mathrm{N}$ (Waring and Bremmer, 1964; Keeney, 1982). Microbial biomass C, MBN, pH, EC $\mathrm{E}_{1: 1}$, and anaerobic potentially-mineralizable $\mathrm{N}$ analyses were made on fresh soil within 2 wk of collection. All other testing was performed on air-dried soil. Data were expressed on a volumetric basis except for $\mathrm{KCl}$-extracted $\mathrm{NO}_{3}-\mathrm{N}$ and $\mathrm{NH}_{4-}$ $\mathrm{N}$, reported as $\mathrm{mg} \mathrm{kg}^{-1}$ soil; and soil moisture, reported as $\mathrm{kg}$ $\mathrm{kg}^{-1}$ soil.

\section{Statistical Analyses}

While soil laboratory analyses were conducted on 0 - to 7.5- and 7.5- to 30-cm depth samples as collected, statistical comparisons were made on $0-$ to $7.5-$ and $0-$ to $30-\mathrm{cm}$ increments. Data from 0- to 7.5- and 7.5- to $30-\mathrm{cm}$ analyses were combined and weighted to calculate $0-$ to $30-\mathrm{cm}$ depth measurements. The significance of classification by $\mathrm{EC}_{\mathrm{a}}$ ranges was determined for each of the soil attributes measured using an ANOVA for a randomized complete block strip-split plot design with crop (wheat, corn, millet or fallow) and $\mathrm{EC}_{\mathrm{a}}$ class as treatment factors. Pearson correlation coefficients were estimated, across replicates and crops, for all pairs of soil variables using both values from all sampling points $(n=96)$ and $\mathrm{EC}_{\mathrm{a}}$ class sample means $(n=4)$. In addition, ANOVA by sampling date were run to compare mean soil gravimetric moisture, water-filled-pore space, and temperature for the two sampling times.

The significance of $\mathrm{EC}_{\mathrm{a}}$ classification to surface residue cover was determined for wheat and fallow fields only with the ANOVA run by crop in order to separate cropped and noncropped effects. Differences were declared significant at the 0.05 level, unless stated otherwise. Correlations between $\mathrm{EC}_{\mathrm{a}}$ and residue were analyzed across replicates by crop, using all sampling points $(n=24)$ and $\mathrm{EC}_{\mathrm{a}}$ class sample means $(n=$ 4). All statistical analyses were performed using SAS (SAS Institute, 1997).

\section{RESULTS AND DISCUSSION Soil Analyses}

The main effect of crop treatment (data not shown) had little effect on soil parameters measured. Differences among crops $(P \leq 0.05)$ were found for $\mathrm{EC}_{1: 1}$ and $\mathrm{pH}$ at the surface $(0-7.5 \mathrm{~cm})$ and for $\mathrm{NO}_{3}-\mathrm{N}$ at both surface and $0-30 \mathrm{~cm}$ depths. It is reasonable that $\mathrm{NO}_{3-}$ $\mathrm{N}$ would differ among cropping treatments given variation in recommended application rates for the different crops. Cornfields received the highest $\mathrm{N}$ rates and showed the highest levels of $\mathrm{NO}_{3}-\mathrm{N}$ following harvest probably due to drought stress and the inability of the plants to fully utilize available $\mathrm{N}$. Both $\mathrm{EC}_{1: 1}$ and $\mathrm{pH}$ are affected by $\mathrm{NO}_{3}-\mathrm{N}$ levels in soil, causing them to show corresponding differences among cropping treatments for surface soils.

Crop $\times \mathrm{EC}_{\mathrm{a}}$ class interactions $(P \leq 0.05)$ were found for only $\mathrm{pH}$ and large-fraction POM $(0.5-2 \mathrm{~mm})$ at the 0-30 cm depth. Levels of POM were highest in the millet and corn treatments as compared with wheat and fallow. This can be attributed to greater residue production by these crops, as well as to the fact that both were preceded by wheat in 1998 (Fig. 1). Conversely, the wheat and fallow treatments produce less (or no) residue and had been cropped during only one of the 1998 and 1999 growing seasons.

With the exception of $\mathrm{KCl}$-extracted $\mathrm{NO}_{3}-\mathrm{N}$ and $\mathrm{NH}_{4}-$ $\mathrm{N}$, all measured soil physical, biological, and chemical parameters were significantly different among $\mathrm{EC}_{\mathrm{a}}$ classes $(P \leq 0.06)$ at one or both sampling depths (Table $2)$. In general, the greatest differences were shown for soil chemical properties, probably because of greater across-site variation. Chemical parameters associated with residue inputs, whole soil organic matter, largefraction POM $(0.5-2 \mathrm{~mm})$, and total $\mathrm{C}$ and $\mathrm{N}$, were significantly different among $\mathrm{EC}_{\mathrm{a}}$ classes at both soil depths. These and other measured parameters, including percentage silt, water content, extractable $\mathrm{P}, \mathrm{MBC}$, MBN, and anaerobic potentially-mineralizable $\mathrm{NH}_{4}$, were negatively correlated with $\mathrm{EC}_{\mathrm{a}}$ at one or both soil depths, suggesting an negative relationship between $\mathrm{EC}_{\mathrm{a}}$ and yield (Table 3 ).

It is reasonable to expect a significant relationship between $\mathrm{EC}_{1: 1}$ and $\mathrm{EC}_{\mathrm{a}}$ since both integrate the effects of clay (type and percentage) and salt content (including 
Table 2. Within-class means and significance of field-scale apparent electrical conductivity $\left(\mathbf{E C}_{\mathrm{a}}\right)$ classification for various soil attributes. The 250-ha experimental site was divided into eight fields planted to two replications of wheat, corn, proso millet, and fallow.

\begin{tabular}{|c|c|c|c|c|c|c|c|c|c|c|c|}
\hline \multirow[b]{4}{*}{ Soil attribute } & \multirow[b]{4}{*}{ Units } & \multicolumn{10}{|c|}{ Soil attribute means within $\mathrm{EC}_{\mathrm{a}}$ classes } \\
\hline & & \multicolumn{10}{|c|}{ EC $_{\mathrm{a}}$ classes $\dagger$} \\
\hline & & \multicolumn{5}{|c|}{ 0- to $7.5-\mathrm{cm}$ depth } & \multicolumn{5}{|c|}{ 0- to 30-cm depth } \\
\hline & & $\mathbf{I}$ & II & III & IV & $\operatorname{Pr}>\boldsymbol{F}$ & $\mathbf{I}$ & II & III & IV & $\boldsymbol{P r}>\boldsymbol{F}$ \\
\hline \multicolumn{12}{|l|}{ Physical } \\
\hline Bulk density & $\mathrm{g} \mathrm{cm}^{-3}$ & 1.38 & 1.47 & 1.51 & 1.56 & 0.06 & 1.32 & 1.39 & 1.39 & 1.42 & 0.06 \\
\hline Sand & $\%$ & 39.8 & 41.9 & 43.4 & 41.3 & 0.06 & 36.4 & 37.3 & 36.9 & 36.2 & n.s. $\neq$ \\
\hline Silt & $\%$ & 42.0 & 39.1 & 36.6 & 36.2 & 0.05 & 40.8 & 38.4 & 35.8 & 35.7 & 0.04 \\
\hline Clay & $\%$ & 18.2 & 19.0 & 20.0 & 22.5 & 0.07 & 22.8 & 24.3 & 27.3 & 28.1 & 0.02 \\
\hline Water content & $\mathrm{kg} \mathrm{kg}^{-1}$ & .160 & .135 & .124 & .118 & 0.002 & .207 & .187 & .185 & .178 & .03 \\
\hline \multicolumn{12}{|l|}{ Chemical } \\
\hline $\mathbf{E C}_{1: 1} \S$ & $\mathbf{d S} \mathbf{m}^{-1}$ & 0.18 & 0.14 & 0.16 & 0.17 & n.s. & 0.16 & 0.15 & 0.19 & 0.22 & 0.006 \\
\hline $\mathbf{N H}_{4}-\mathbf{N}$ & $\mathrm{mg} \mathrm{kg}^{-1}$ & 0.071 & 0.028 & 0.081 & 0.071 & n.s. & 0.222 & 0.223 & 0.214 & 0.184 & n.s. \\
\hline $\mathbf{N O}_{3}-\mathbf{N}$ & $\mathbf{m g ~ k g} \mathbf{~}^{-1}$ & 7.2 & 5.3 & 5.5 & 6.1 & n.s. & 5.6 & 4.0 & 4.2 & 4.5 & n.s. \\
\hline SOMII & $\mathrm{Mg} \mathrm{ha}^{-1}$ & 34.1 & 31.3 & 28.4 & 28.3 & 0.05 & 124.8 & 115.9 & 110.4 & 112.6 & 0.05 \\
\hline PH & & 6.22 & 6.21 & 6.38 & 6.51 & n.s. & 6.33 & 6.42 & 6.72 & 6.92 & 0.01 \\
\hline Extractable $\mathbf{P}$ & $\mathrm{kg} \mathrm{ha}^{-1}$ & 41.9 & 29.8 & 15.7 & 13.0 & 0.004 & 111.8 & 69.2 & 27.8 & 26.7 & 0.002 \\
\hline POM\# (0.05-0.5 mm) & $\mathrm{Mg} \mathrm{ha}^{-1}$ & 5.93 & 5.36 & 4.18 & 3.96 & 0.01 & 14.42 & 11.94 & 11.08 & 12.02 & 0.04 \\
\hline POM $(0.5-2 \mathrm{~mm})$ & Mg ha $^{-1}$ & 2.30 & 2.16 & 1.60 & 1.70 & 0.02 & 4.22 & 3.78 & 3.28 & $\mathbf{3 . 3 7}$ & n.s. \\
\hline POM (0.05-2 mm) & Mg ha $^{-1}$ & 7.69 & 7.05 & 5.36 & 5.24 & 0.001 & 17.73 & 14.89 & 13.67 & 14.76 & n.s. \\
\hline Total C & Mg ha $^{-1}$ & 13.4 & 11.3 & 9.5 & 9.2 & 0.004 & 43.8 & 35.2 & 32.2 & 32.7 & 0.009 \\
\hline Total $\mathbf{N}$ & $\operatorname{Mg~ha}^{-1}$ & 1.20 & 1.04 & 0.91 & 0.87 & 0.006 & 4.08 & 3.45 & 3.09 & 3.10 & 0.001 \\
\hline \multicolumn{12}{|l|}{ Biological } \\
\hline Microbial biomass C & $\mathrm{kg} \mathrm{ha}^{-1}$ & 418.6 & 357.8 & 293.7 & 286.5 & 0.04 & 545.3 & 544.8 & 425.8 & 442.0 & n.s. \\
\hline Microbial biomass $\mathbf{N}$ & $\mathrm{kg} \mathrm{ha}^{-1}$ & 45.1 & 40.3 & 36.0 & 31.6 & 0.002 & 57.9 & 53.1 & 54.9 & 52.4 & n.s. \\
\hline PMN NH $\mathbf{N H}_{4} \dagger$ & $\mathrm{kg} \mathrm{ha}^{-1}$ & 45.1 & 36.0 & 32.7 & 26.9 & 0.02 & 86.4 & 67.0 & 59.3 & 54.4 & .04 \\
\hline
\end{tabular}

$\dagger$ Each of the eight fields within the study site was individually classified into four conductivity ranges, and each range was sampled in triplicate at two

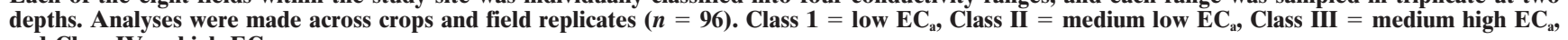
and Class IV = high $\mathbf{E C}_{\mathrm{a}^{*}}$

+ n.s. $=$ Non-significant $F$-value at the 0.1 level.

$\S \mathbf{E C}_{1: 1}=$ laboratory measured $\mathbf{E C}$ using a 1:1 water saturated paste.

II $\mathrm{SOM}=$ total soil organic matter by loss-on-ignition.

\# POM = particulate organic matter by loss-on-ignition.

$\dagger+$ PMN NH $\mathbf{N H}_{4}=$ potentially mineralizable $\mathrm{NH}_{4}^{+}$.

soluble anions and cations). The two measures differ in that $\mathrm{EC}_{1: 1}$ allows for the standardization of soil water. While this difference will affect the magnitude of measured EC, a degree of correlation should still exist between $\mathrm{EC}_{1: 1}$ and $\mathrm{EC}_{\mathrm{a}}$, dependent upon the extent to which clay type and percentage and salt content contribute to measured conductivity. In this study, surface soil analyses of $\mathrm{EC}_{1: 1}$ were not related to $\mathrm{EC}_{\mathrm{a}}$ classification. However, $\mathrm{EC}_{1: 1}$ was differentiated by $\mathrm{EC}_{\mathrm{a}}$ classification when the two analyses were based upon a similar depth of measurement $(0-30 \mathrm{~cm})$ (Table 2 and 3). Soil $\mathrm{pH}$, which typically shows a strong relationship with $\mathrm{EC}_{1: 1}$ (Patriquin et al., 1993), was also significantly different among $\mathrm{EC}_{\mathrm{a}}$ classes in deep $(0-30 \mathrm{~cm})$ soils.

Potassium chloride-extracted $\mathrm{NO}_{3}-\mathrm{N}_{\text {and }} \mathrm{NH}_{4}-\mathrm{N}$ were not significantly partitioned by $\mathrm{EC}_{\mathrm{a}}$ classification and exhibited a narrow range of variability across the experimental site. Nitrogen transformations in soil are controlled by soil water content, texture, biological activity, cropping, and the composition and quantity of organic matter (Stevenson, 1982). These soil characteristics impact the discordant processes of volatilization, nitrification, immobilization, and leaching (losses) or mineralization (gains) that define levels of soil inorganic $\mathrm{N}$ (Jansson and Persson, 1982; Stevenson, 1982). Our analyses indicate that, at the time of sample collection, available $\mathrm{N}$ levels were not related to variability in soil condition. In this study it should also be noted that, prior to soil sampling, millet and corn crops were severely drought stressed at critical growth stages during July and August. Since adequate moisture is essential for effective crop uptake of N (Olson, 1984), erratic acrossfield crop demand for available $\mathrm{N}$ may have altered its spatial variation. It is also possible that for this location, factors other than inorganic $\mathrm{N}$ dominate measured $\mathrm{EC}_{\mathrm{a}}$.

Physical soil attributes of texture and bulk density, although less effectively partitioned than chemical and biological attributes, were still different among the $\mathrm{EC}_{\mathrm{a}}$ classes (Table 2). The one exception was percentage sand at the 0 - to $30-\mathrm{cm}$ depth, which was uniform across sampling sites. As per other reports (Kachanoski et al., 1988; Khakural and Robert, 1998), positive correlations were found between $\mathrm{EC}_{\mathrm{a}}$ and clay content (Table 3), with clay content ranging between 12.2 and $38.8 \%$ in sampled soils.

All measured biological parameters, $\mathrm{MBC}, \mathrm{MBN}$, and anaerobic potentially-mineralizable $\mathrm{NH}_{4}$, were significantly different among $\mathrm{EC}_{\mathrm{a}}$ classes in the 0 - to $7.5-\mathrm{cm}$ depth only (Table 2$)$. Correlations between $\mathrm{EC}_{\mathrm{a}}(\approx 30$ $\mathrm{cm}$ depth) and soil surface measurements $(0-7.5 \mathrm{~cm})$ of moisture and biological activity were stronger than those between $\mathrm{EC}_{\mathrm{a}}$ and the same measurements taken at $0-$ to $30-\mathrm{cm}$ (Table 3). This may suggest some $\mathrm{EC}_{\mathrm{a}}$ bias toward soil surface conditions.

It is interesting to note that when correlation analyses were conducted using $\mathrm{EC}_{\mathrm{a}}$ class means $(n=4)$ for soil parameters, as opposed to using values from all sampling points $(n=24)$, the relationships between $\mathrm{EC}_{\mathrm{a}}$ and those parameters improved dramatically (data not shown). All measured parameters, except percentage 


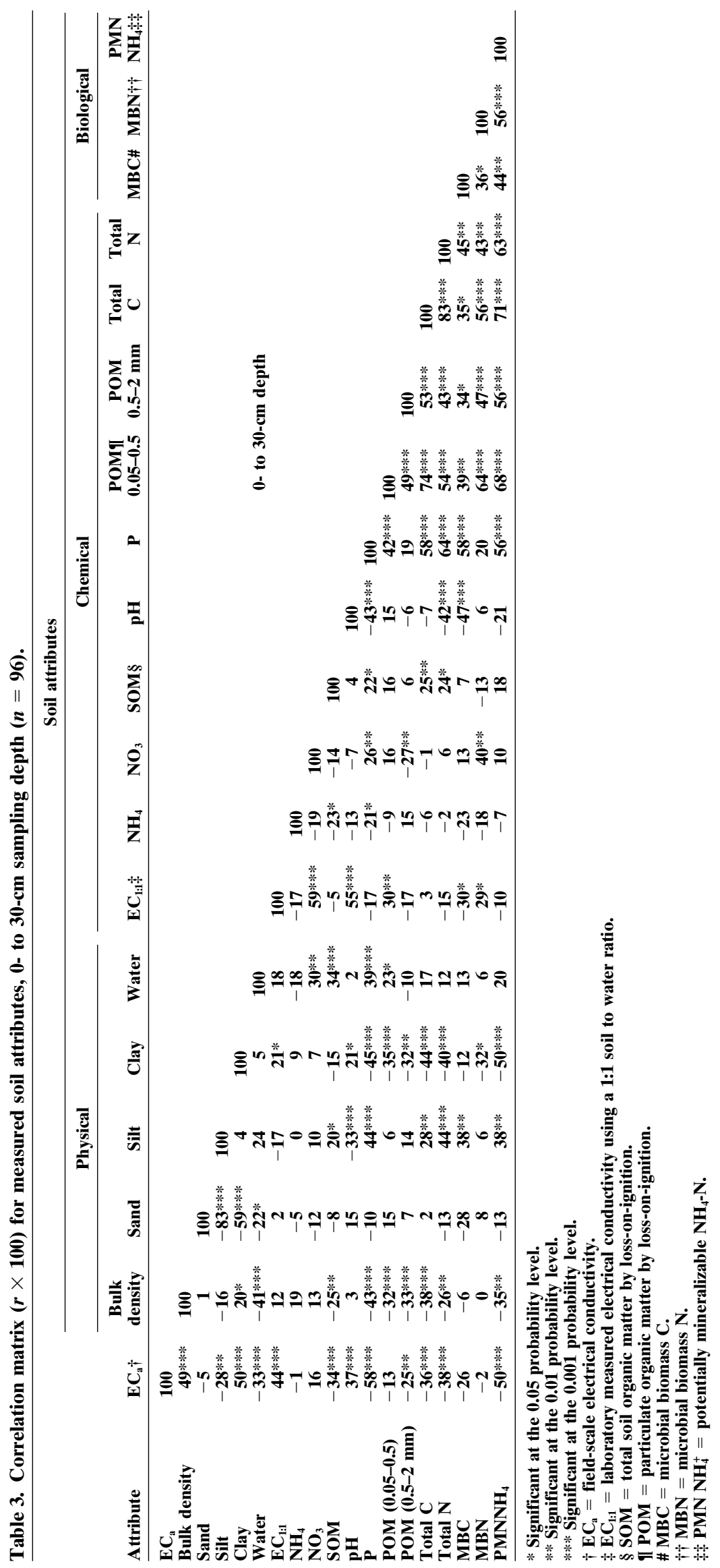


sand and $\mathrm{NO}_{3}-\mathrm{N}$, were highly correlated with $\mathrm{EC}_{\mathrm{a}}(r \geq$ 0.80 ) at one or both sampling depths. We know that measured $\mathrm{EC}_{\mathrm{a}}$ synthesizes the effects of certain static and dynamic soil characteristics; these characteristics are, in turn, correlated with other soil properties that underlie overall soil condition and productivity. Highly variable levels of a specific soil parameter can be associated with a single $\mathrm{EC}_{\mathrm{a}}$ value due to the buffering effect of corresponding variations in opposing soil parameters affecting $\mathrm{EC}_{\mathrm{a}}$. Consequently, for this experimental site strong correlations do not exist between $\mathrm{EC}_{\mathrm{a}}$ and individual soil parameters at point sources. Field-scale apparent electrical conductivity appears to be a tool most useful for the delineation of overall soil condition.

Under the conditions of this study, primary factors contributing to measured $\mathrm{EC}_{\mathrm{a}}$ can be separated into static (clay percentage) and dynamic components (soil moisture and salinity). Soil clay content $(0-30 \mathrm{~cm})$ was negatively correlated with parameters associated with productivity including $\mathrm{P}, \mathrm{POM}$, total $\mathrm{C}$ and $\mathrm{N}, \mathrm{MBN}$, and potentially-mineralizable $\mathrm{N}$, all of which are strongly auto-correlated (Table 3). On the other hand, clay content was positively correlated with $\mathrm{pH}$ and bulk density. These relationships are likely due to the calcareous nature of soils in northeastern Colorado, where the erosion of topsoil exposes underlying soil horizons that are characterized by increased clay content and $\mathrm{CaCO}_{3}$ and associated elevation of bulk density and $\mathrm{pH}$.

Other potential contributors to $\mathrm{EC}_{\mathrm{a}}$, soil moisture content, and $\mathrm{NO}_{3}-\mathrm{N}$ are correlated with both $\mathrm{P}$ and POM components of the soil and with each other. The lack of significant correlation between $\mathrm{NO}_{3}-\mathrm{N}$ and $\mathrm{EC}_{\mathrm{a}}$ suggests that it had minimal impact on $\mathrm{EC}_{\mathrm{a}}$ for these sampling times. While soil moisture generally increases with increasing clay content, there is no correlation between the two for the soils under study. For this site, increases in soil water-holding capacity due to the presence of clay are probably offset by concomitant decreases in soil organic matter components and soil depth. Furthermore, in semiarid environments, plantavailable water and crop yields are less defined by the ability of soil to store water than by precipitation inputs.

\section{Residue Analyses}

As harvest index relationships between wheat grain mass and aboveground biomass are well accepted, it is likely that the measured across-field variation in residue mass mirrors that of crop yields. Surface residue cover measured at each of the wheat and fallow soil-sampling sites was significantly related to $\mathrm{EC}_{\mathrm{a}}$ classification and negatively correlated with $\mathrm{EC}_{\mathrm{a}}$ (Fig. 3). As would be expected for a collection date shortly after wheat harvest, residue quantity in wheat fields $(1375-8459 \mathrm{~kg}$ $\mathrm{ha}^{-1}$ ) was approximately twice that in fallow fields (582-5005 $\left.\mathrm{kg} \mathrm{ha}^{-1}\right)$. Residue mass in fallow fields was slightly less correlated with $\mathrm{EC}_{\mathrm{a}}(r=-0.91)$ than that of wheat fields $(r=-0.95)$, probably because of differential decomposition and redistribution by wind and water. Tremendous variability in residue quantity was found within $\mathrm{EC}_{\mathrm{a}}$ classes, particularly in low $\mathrm{EC}_{\mathrm{a}}$ (high

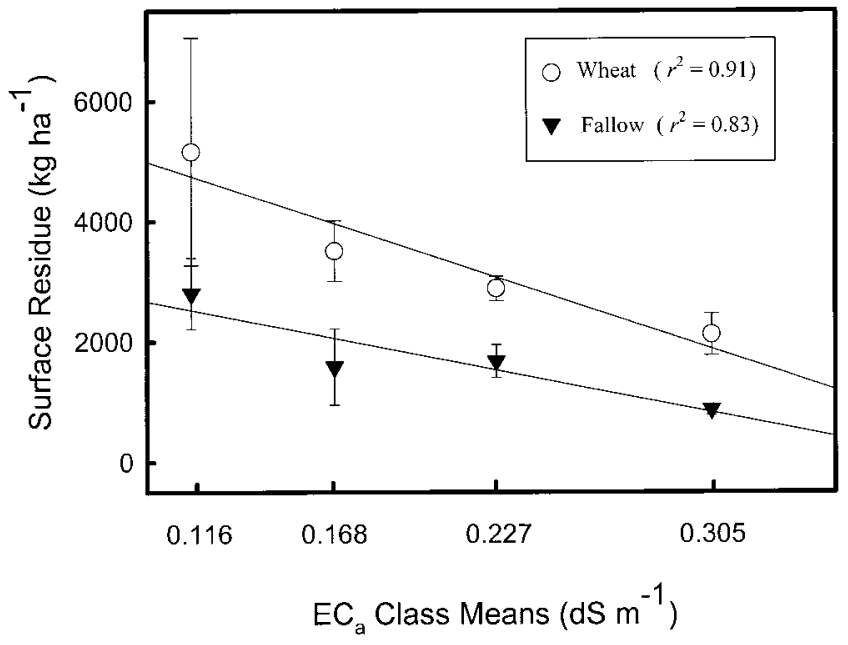

Fig. 3. Relationship between surface residue content and field-scale apparent electrical conductivity $\left(\mathrm{EC}_{\mathrm{a}}\right)$. Each point represents the mean of six samples. The error bars depict the standard errors of the mean.

residue) zones. Accordingly, correlations between surface residue and $\mathrm{EC}_{\mathrm{a}}$ declined $(r=-0.54$ and -0.62 , respectively, for wheat and fallow fields) when analyzed using data from all sampling points $(n=24)$.

\section{Electrical Conductivity Mapping and Classification}

Apparent vestiges of both historical and recent management are evident in the $\mathrm{EC}_{\mathrm{a}}$ map generated in this field study. Careful examination of the map reveals $\mathrm{V}$ shaped patterns in each of the four corner fields of the section (Fig. 1 and 2). These anomalies are believed to be remnants of the plow path followed in the 1930s when the study site was farmed as two half sections. Additionally, each of the four field pairs within the section, having similar recent management histories, is distinguished by varying mean levels of conductivity. The two fields of actively growing wheat, at the time of $\mathrm{EC}_{\mathrm{a}}$ mapping, register the lowest overall conductivity. This can not be attributed to soil water content since the water content of soil under a growing crop would be less than that in fallow fields, and water content is negatively correlated with $\mathrm{EC}_{\mathrm{a}}$ at this site. Two possible explanations may be offered for this phenomenon. An $\mathrm{EC}_{\mathrm{a}}$ bias toward the soil surface may exist where the growing crop and associated microbial activity reduce levels of available $\mathrm{N}$, and hence $\mathrm{EC}_{\mathrm{a}}$ (Eigenberg et al., 2001). Alternatively, the loosening of soil during planting or with plant root activity may lower soil bulk density and $\mathrm{EC}_{\mathrm{a}}$ (E. Lund, 2001, personal communication).

Soil temperatures $(0-7.5 \mathrm{~cm})$ were fairly uniform across the study site for each sampling date, but were significantly different among dates (Table 4). Gravimetric water content and water-filled pore space were quite similar, albeit significantly different, among sampling dates. Although both soil temperature and moisture content affect measured $\mathrm{EC}_{\mathrm{a}}$, the design of this experiment is based upon the assumption that the relevance of established $\mathrm{EC}_{\mathrm{a}}$ zones does not change over time 
Table 4. Mean soil temperature, moisture content, and waterfilled pore space for the two sampling dates.

\begin{tabular}{|c|c|c|c|c|c|}
\hline \multirow[b]{2}{*}{ Sampling date } & \multirow{2}{*}{$\begin{array}{c}\text { Mean soil } \\
\text { temperature } \\
0-7.5 \mathrm{~cm}\end{array}$} & \multicolumn{2}{|c|}{$\begin{array}{l}\text { Mean soil } \\
\text { moisture }\end{array}$} & \multicolumn{2}{|c|}{$\begin{array}{c}\text { Mean soil } \\
\text { water-filled } \\
\text { pore space }\end{array}$} \\
\hline & & $0-7.5 \mathrm{~cm}$ & $0-30 \mathrm{~cm}$ & $0-7.5 \mathrm{~cm}$ & $0-30 \mathrm{~cm}$ \\
\hline & ${ }^{\circ} \mathrm{C}$ & kg & & $-\%$ & \\
\hline $15 \mathrm{f}$ & $26.7 \dagger$ & 0.150 & 0.190 & 45.8 & 54.3 \\
\hline $16 \mathrm{No}$ & 12. & & 0.1 & 45.0 & 48.3 \\
\hline $\mathbf{S E}_{\mathrm{d}} \neq$ & 0.58 & 0.004 & 0.002 & 1.61 & 0.87 \\
\hline
\end{tabular}

$\dagger$ Values within a column are significant different $(P=\mathbf{0 . 0 0 0 1})$.

$\$ \mathrm{SE}_{\mathrm{d}}=$ Standard error of the difference between sample date means.

with fluctuations in dynamic soil properties. It has been demonstrated that, while the magnitude of temporal $\mathrm{EC}_{\mathrm{a}}$ measurements varies with soil moisture and temperature, spatial patterns in $\mathrm{EC}_{\mathrm{a}}$ remain constant (Sudduth et al., 2000; Veris Technologies, 2001). This finding is essential to the use of $\mathrm{EC}_{\mathrm{a}}$ mapping as a basis for identifying soil-sampling zones.

The number of $\mathrm{EC}_{\mathrm{a}}$ classes, into which a field is separated for sampling or management purposes, depends upon desired measurement sensitivity and the level of within-field variability. For this study, separation into four $\mathrm{EC}_{\mathrm{a}}$ classes (ranges) proved to be a good compromise between sensitivity and visually discernable patterns in $\mathrm{EC}_{\mathrm{a}}$ (Fig. 2).

\section{CONCLUSIONS}

The $\mathrm{EC}_{\mathrm{a}}$ vs. yield relationship varies among published accounts, and inconsistent correlations have been found between $\mathrm{EC}_{\mathrm{a}}$ and crop yield across years (Jaynes et al., 1995; Kitchen et al., 1999). However, these studies have been conducted in high-rainfall regions where yield reductions occur due to both drought and excessive precipitation. Typically in the Central Great Plains, where insufficient precipitation poses the primary limitation to crop production, crop yield varies with degree of drought stress. In this environment, $\mathrm{EC}_{\mathrm{a}}$ may be a more consistent predictor of yield potential across years.

For this study site, soil parameters associated with erosion phase including percentage clay, bulk density, $\mathrm{pH}$, and $\mathrm{EC}_{1: 1}$ were positively correlated with $\mathrm{EC}_{\mathrm{a}}$ measurements integrated over a soil depth of $\approx 0$ to $30 \mathrm{~cm}$. Other properties related to crop productivity, notably soil moisture, total and $\mathrm{POM}$, total $\mathrm{C}$ and $\mathrm{N}$, MBC and MBN, and surface-residue content, were negatively correlated. These results imply a negative relationship between $\mathrm{EC}_{\mathrm{a}}$ and productivity. The application of spatial techniques to $\mathrm{EC}_{\mathrm{a}}$ and yield maps from the experimental site will provide verification of the statistical associations between $\mathrm{EC}_{\mathrm{a}}$ and yield; these analyses will be the focus of a future publication.

In view of the large number of soil samples required for representative estimates of overall-field condition, traditional grid sampling is both expensive and labor intensive. One of the best ways to reduce these costs is to minimize the number of samples required through zone sampling. Zone sampling, based on a combination of soil color, texture, depth, slope, and erosion characteristics, has been shown to be an effective alternative to grid sampling (Francis and Schepers, 1997). In fact, the $\mathrm{EC}_{\mathrm{a}}$-classed soil-sampling scheme used in this study appears to integrate these and other soil characteristics. We found that $E_{a}$ classification effectively delimits distinct zones of soil condition, making it an excellent basis for soil sampling to reflect spatial heterogeneity.

Chen et al. (2000) used soil color, quantified through remotely-sensed imaging, to predict $\mathrm{C}$ levels as an indicator of soil condition. Like $\mathrm{EC}_{\mathrm{a}}$, remote sensing was found to be a cost-effective basis for delineating soil spatial variability. However, while remotely sensed imagery is typically applied to bare (tilled) soil, $\mathrm{EC}_{\mathrm{a}}$ has the advantage of effectiveness for cropped land where no-till management is practiced.

Currently, most farmers in the Central Great Plains apply management practices uniformly across a field. In this approach, management decisions are based upon measured soil attributes expressed as whole-field averages. The software used to assign $\mathrm{EC}_{\mathrm{a}}$ classes can also generate class areas (ha class ${ }^{-1}$ ) within fields. Thus, whole-field means for specific soil analyses can be easily calculated. $\mathrm{EC}_{\mathrm{a}}$ class sample means are simply weighted, relative to class area within the whole field, summed, and divided by the number of classes. This approach is superior to traditional random sampling because it accounts for spatial heterogeneity of soil attributes in the sampling design; moreover, whole field means based on stratified sampling have smaller standard errors than are possible with random sampling.

Soil classification using $\mathrm{EC}_{\mathrm{a}}$ provides an effective basis for delineating interrelated physical, chemical, and biological soil attributes that are expressed as soil condition, crop productivity, and ecological potential. It offers a useful framework for soil sampling to reflect spatial heterogeneity and can be potentially applied to assess temporal impacts of management on soil condition. Furthermore, as variable rate planters, sprayers, and applicators become more refined and cost effective, classification based on $\mathrm{EC}_{\mathrm{a}}$ can provide spatial data regarding soil condition and yield potential that will serve as an essential link between this new technology and effective management.

\section{ACKNOWLEDGMENTS}

We gratefully acknowledge Russ and Matt Johnson, landowners and managers of the experimental site, without whom this study would not be possible. The expertise of Timothy Kettler, Michael Schlemmer, Aaron Schepers, and Hamid Farahani was invaluable to the success of this experiment. We thank Randy Anderson and the USDA-ARS Central Great Plains Research Station in Akron, CO, for the use of their soil sampler. The technical assistance of Tara Gilbert, John Bricker, Susan Wagner, Spencer Arnold, Igor Coelho, Bob Florian, and Gene Uhler is also much appreciated.

\section{REFERENCES}

Bray, R.H., and L.T. Kurtz. 1945. Determination of total, organic, and available forms of phosphorus in soils. Soil Sci. 59:39-45.

Bauer, A., and A.L. Black. 1994. Quantification of the effect of soil organic matter content on soil productivity. Soil Sci. Soc. Am. J. 58:185-193.

Cambardella, C.A., A.M. Gajda, J.W. Doran, B.J. Wienhold, and T.A. 
Kettler. 2001. Estimation of particulate and total organic matter by weight loss on ignition. p. 349-359. In R. Lal et al. (ed.) Assessment methods for soil carbon. CRC Press, Boca Raton, FL.

Chen, F., D.E. Kissel, L.T. West, and W. Adkins. 2000. Field-scale mapping of surface soil organic carbon using remotely sensed imagery. Soil Sci. Soc. Am. J. 64:746-753.

Cook, C.W., and J. Stubbendieck. 1986. Range research. Soc. For Range Manage. Denver, CO.

Dolittle, J., E. Ealy, G. Secrist, D. Rector, and M. Crouch. 1995. Reconnaissance soil mapping of a small watershed using electromagnetic induction and global positioning system techniques. Soil Surv. Horiz. 36:86-94.

Doran, J.W., and T.B. Parkin. 1996. Quantitative indicators of soil quality: a minimum data set. p. 25-38. In J.W. Doran and A.J. Jones (ed.) Methods for assessing soil quality. SSSA Spec. Publ. 49. SSSA, Madison, WI.

Eigenberg, R.A., J.W. Doran, J.A. Nienaber, R.B. Ferguson, and B.L. Woodbury. 2002. Electrical conductivity monitoring of soil condition and available $\mathrm{N}$ with animal manure and a cover crop. Special issue on soil health as an indicator of sustainable management. Agric. Ecosyst. Environ. (in press).

ERDAS. 1997. ERDAS Field Guide. p. 225-232. ERDAS, Inc., Atlanta, GA.

Francis, D.D., and J.S. Schepers. 1997. Selective soil sampling for sitespecific nutrient management. p. 119-126. In J.V. Stafford (ed.) Precision agriculture-'97. Proc. Eur. Conf. on Precision Agriculture, 1st, Warwick University Conference Centre. 7-10 Sept. 1997. BIOS Scientific Publishers Ltd., Oxford, UK.

Fritz, R.M., D.D. Malo, T.E. Schumacher, D.E. Clay, and C.G. Carlson. 1999. Field comparison of two soil electrical conductivity measurement systems. p. 1211-1217. In Int. Conf. on Precision Agriculture, 4th, St. Paul, MN. 19-22 June. ASA, CSSA, and SSSA, Madison, WI

Gardner, J.C., and S.A. Clancy. 1996. Impact of farming practices on soil quality in North Dakota. p. 337-343. In J.W. Doran and A.J. Jones (ed.) Methods for assessing soil quality. SSSA Spec. Publ. 49. SSSA, Madison, WI.

Islam, K.R., R.R. Weil, and C.L. Mulchi. 1998. Microwave irradiation of soil for routine measurement of microbial biomass carbon. Biol. Fert. Soils. 27:408-416.

Jansson, S.L., and J. Persson. 1982. Mineralization and immobilization of soil nitrogen. p. 229-252. In F.J. Stevenson (ed.) Nitrogen in agricultural soils. Agron. Monogr. 22. ASA, CSSA, and SSSA, Madison, WI.

Jaynes, D.B. 1996. Improved soil mapping using electromagnetic induction surveys. p. 169-179. In P.C. Robert et al. (ed.) Proc. Int Conf. on Precision Agriculture, 3rd, Minneapolis, MN. 23-26 June 1996. ASA, CSSA, and SSSA, Madison, WI.

Jaynes, D.B., T.S. Colvin, and J. Ambuel. 1995. Yield mapping by electromagnetic induction. p. 383-394. In P.C. Robert et al. (ed.) Proc. of site-specific management for agricultural systems, 2nd, Minneapolis, MN. 27-30 Mar. 1994. University of Minnesota Extension Service, Minneapolis, MN.

Kachanoski, R.G., E.G. Gregorich, and I.J. Van Wesenbeeck. 1988. Estimating spatial variations of soil water content using noncontacting electromagnetic inductive methods. Can. J. Soil Sci. 68:715722.

Keeney, D.R. 1982. Recommended biological index-ammonium-nitrogen production under waterlogged conditions. p. 727-728. In A.L. Page et al. (ed.) Methods of soil analysis. Part 2. 2nd ed. Agron. Monogr. no. 9. ASA and SSSA, Madison, WI.

Kettler, T.A., J.W. Doran, and T.L. Gilbert. A simplified method for soil particle size determination to accompany soil quality analyses. Soil Sci. Soc. Am. J. 65:849-852.

Khakural, B.R., and P.C. Robert. 1998. Use of non-contacting electromagnetic inductive method for estimating soil moisture across a landscape. Commun. Soil Sci. Plant Anal. 29:2055-2065.

Kitchen, N.R., K.A. Sudduth, and S.T. Drummond. 1999. Soil electrical conductivity as a crop productivity measure for claypan soils. J. Prod. Agric. 12:607-617.

Lark, R.M. 1997. Variation in soil conditions and crop performance. p. 127-135. In J.V. Stafford (ed.) Precision agriculture-'97. Proc.
Eur. Conf. on Precision Agriculture, 1st, Warwick University Conference Centre. 7-10 Sept. 1997. BIOS Scientific Publishers Ltd., Oxford, UK.

Lesch, S.M., J.D. Rhoades, L.J. Lund, and D.L. Corwin. 1992. Mapping soil salinity using calibrated electromagnetic measurements. Soil Sci. Soc. Am. J. 56:540-548.

McBride, R.A., A.M. Gordon, and S.C. Shrive. 1990. Estimating forest soil quality from terrain measurements of apparent electrical conductivity. Soil Sci. Soc. Am. J. 54:290-293.

McNeill, J.D. 1980. Electrical conductivity of soils and rocks. Tech. note TN-5. Geonics Ltd., Mississauga, ON, Canada.

Olson, G.L., B.G. McQuaid, K.N. Easterling, and J.M. Scheyer. 1996 Quantifying soil condition and productivity in Nebraska. p. 357369. In J.W. Doran and A.J. Jones (ed.) Methods for assessing soil quality. SSSA Spec. Publ. 49. SSSA, Madison, WI

Olson, R.A. 1984. Nitrogen use in dryland farming under semiarid conditions. p. 335-347. In R.D. Hauck (ed.) Nitrogen in crop production. ASA, CSSA, and SSSA, Madison, WI.

Patriquin, D.G., H. Blaikie, M.J. Patriquin, and C. Yang. 1993. Onfarm measurements of $\mathrm{pH}$, electrical conductivity and nitrate in soil extracts for monitoring coupling and decoupling of nutrient cycles. Biol. Agric. Hortic. 9:231-272.

Rhoades, J.D., N.A. Manteghi, P.J. Shouse, and W.J. Alves. 1989. Soil electrical conductivity and soil salinity: new formulations and calibrations. Soil Sci. Soc. Am. J. 53:433-439.

Rhoades, J.D., and R.D. Ingvalson. 1971. Determining salinity in field soils with soil resistance measurements. Soil Sci. Soc. Am. Proc. 35:54-60.

Rhoades, J.D., and D.L. Corwin. 1981. Determining soil electrical conductivity-depth relations using an inductive electromagnetic soil conductivity meter. Soil Sci. Soc. Am. J. 45:255-260.

SAS Institute. 1997. SAS/STAT Software: Changes and enhancements through release 6.12. SAS Inst., Cary, NC.

Sheets, K.R., and J.M.H. Hendrickx. 1995. Noninvasive soil water content measurement using electromagnetic induction. Water Res. 31:2401-2409.

Smith, J.L., and J.W. Doran. 1996. Measurement and use of pH and electrical conductivity for soil quality analysis. p. 169-185. In J.W. Doran and A.J. Jones (ed.) Methods for assessing soil quality. SSSA Spec. Publ. 49. SSSA, Madison, WI.

Stevenson, F.J. 1982. Origin and distribution of nitrogen in soil. p. 1-42. In F.J. Stevenson (ed.) Nitrogen in agricultural soils. Agron. Monogr. 22. ASA, CSSA, and SSSA, Madison, WI.

Sudduth, K.A., S.T. Drummond, and N.R. Kitchen. 2000. Measuring and interpreting soil electrical conductivity for precision agriculture. p. 1444-1451. In Proc. Int. Conf. Geospatial Information in Agriculture and Forestry, 2nd, Lake Buena Vista, FL. 10-12 June 2000. ERIM International, Inc., Ann Arbor, MI.

Sudduth, K.A., D.F. Hughes, and S.T. Drummond. 1995. Electromagnetic induction sensing as an indicator of productivity on claypan soils. p. 671-681. In P.C. Robert et al. (ed.) Proc. Int. Conf. on SiteSpecific Management for Agricultural Systems, 2nd, Minneapolis, MN. 27-30 March 1994. ASA, CSSA, and SSSA, Madison, WI.

Sudduth, K.A., N.R. Kitchen, and S.T. Drummond. 1999. Soil conductivity sensing on claypan soils: comparison of electromagnetic induction and direct methods. p. 979-990. In Proc. Int. Conf. on Precision Agriculture, 4th, St. Paul, MN. 19-22 June. ASA, CSSA, and SSSA, Madison, WI.

Vanden Heuvel, R.M. 1996. The promise of precision agriculture. J. Soil Water Conserv. 51:38-40.

Veris Technologies. 2001. Frequently asked questions about soil electrical conductivity [Online]. [2 p.] Available at: http://www. veristech.com [modified 31 May 2001; cited 3 Feb. 2001; verified 25 June 2001]. Veris Technologies, Salina, KS.

Wallace, A. 1994. High-precision agriculture is an excellent tool for conservation of natural resources. Commun. Soil Sci. Plant Anal. 25: 45-49.

Waring, S.A., and J.M. Bremmer. 1964. Ammonium production in soil under waterlogged conditions as an index on nitrogen availability. Nature 201:951-952.

Williams, B.G., and D. Hoey. 1987. The use of electromagnetic induction to detect the spatial variability of the salt and clay contents of soils. Aust. J. Soil Res. 25:21-27. 